\title{
High hydrostatic pressure modification of whey protein concentrate for use in low-fat whipping cream improves foaming properties
}

\author{
C. A. Padiernos, S.-Y. Lim, B. G. Swanson, C. F. Ross, and S. Clark ${ }^{1}$ \\ Department of Food Science and Human Nutrition, Washington State University, Pullman 99164-6376
}

\begin{abstract}
Whey is the inevitable by-product of cheese production. Whey can be incorporated into a variety of foods, but little has been done to investigate its suitability in whipping cream. The objective of this work was to evaluate the foaming properties of selected low-fat whipping cream formulations containing whey protein concentrate (WPC) that did or did not undergo high hydrostatic pressure (HHP) treatment. Fresh whey was concentrated by ultrafiltration, pasteurized, and standardized to $8.23 \%$ total solids and treated with HHP at $300 \mathrm{MPa}$ for $15 \mathrm{~min}$. Viscosity, overrun, and foam stability were determined to assess foaming properties. Sensory evaluation was conducted with 57 panelists using a duo-trio difference test. The optimal whipping time for the selected formulations was $3 \mathrm{~min}$. Whipping cream containing untreated WPC and HHP-treated WPC resulted in greater overrun and foam stability than the control whipping cream without WPC. Panelists distinguished a difference between whipping cream containing untreated WPC and whipping cream containing HHP-treated WPC. High hydrostatic pressuretreated WPC can improve the foaming properties of low-fat whipping cream, which may justify expansion of the use of whey in whipping cream and application of HHP technology in the dairy industry.
\end{abstract}

Key words: whey protein concentrate, high hydrostatic pressure, low-fat whipping cream, foam stability

\section{INTRODUCTION}

The US dairy industry produced approximately 179 million $\mathrm{kg}$ of whey proteins in 2007 (Gould, 2008). Disposal of whey, the by-product produced during the manufacture of cheese, is a problem in the dairy industry because of the high biochemical oxygen demand (32,000 to $60,000 \mathrm{mg} / \mathrm{kg}$; Cancino et al., 2006). Thus,

Received December 23, 2008

Accepted March 10, 2009.

${ }^{1}$ Corresponding author: stephclark@wsu.edu membrane applications are good alternatives for whey treatment. An appropriate membrane can simultaneously fractionate, purify, and concentrate whey components (Cancino et al., 2006). Several membrane technologies such as UF, microfiltration, nanofiltration, and reverse osmosis can decrease the biochemical oxygen demand values and increase the production opportunities for whey protein concentrate (WPC; Rosenberg, 1995; Cancino et al., 2006).

For many years, WPC of selected protein concentrations have been used successfully in formulated food products to enhance important functionalities of certain foods (Li et al., 2005). The popularity of WPC as a food ingredient results from the functional properties of whey, including improvement of solubility, foam stability, emulsification, gelation, water binding, and viscosity (Banavara et al., 2003). Relkin and Sourdet (2005) reported that whey proteins added to whipped-frozen emulsions stabilized the structure. Although WPC is popularly used as an ingredient in frozen desserts, baked goods, beverages, and meat products, the expanded development of whey protein functionalities is the key for promoting the use of WPC (Liu et al., 2005a,b; Lim et al., 2008a,b). One of the promising applications of WPC is use as a food ingredient in low-fat whipping cream to improve foaming properties, because WPC supports emulsification, flavor, texture, color, viscosity, foam stability, whipping, and nutrition (Foegeding et al., 2006). Whipping cream is a liquid cream that must contain more than $30 \%$, but less than $36 \%$, fat. Low-fat whipping cream must contain less than $3 \mathrm{~g}$ of fat per 30-g serving (US FDA, 2006).

Whey proteins are very important food ingredients because of their functional properties. High hydrostatic pressure (HHP) induces changes that alter the functional properties for different food applications (LópezFandiño, 2006). The functional properties of WPC can be modified through the use of HHP processing, involving elevated pressures ranging from 100 to 1,000 $\mathrm{MPa}$, with or without the addition of heat (Rodiles-López et al., 2008). High hydrostatic pressure is one of the many alternative methods of modifying the molecular structure and physical properties of food constituents and improving food quality (Gervilla et al., 1997; García- 
Risco et al., 2000; Ramaswamy et al., 2006). Lim et al. (2008a) reported that the solubility of WPC (HHPtreated at 300, 400, and $600 \mathrm{MPa}$ at 0 - and 15-min holding times, $\mathrm{pH} 7$ ) did not change significantly, and good overrun and foam stability were obtained after a pressure-time combination of $300 \mathrm{MPa}$ for $15 \mathrm{~min}$. The application was expanded to demonstrate that HHPtreated WPC improved viscosity, overrun, and foam stability of low-fat ice cream (Lim et al., 2008b). The hypothesis of the present research was that use of HHPtreated WPC would improve the foaming properties of low-fat whipping cream compared with traditional low-fat whipping cream or low-fat whipping cream with untreated WPC. Improvements in the foaming properties of low-fat whipping creams with the incorporation of WPC may positively affect the dairy industry by increasing the incorporation of HHP-treated WPC in reduced-fat dairy products. The present study validates the application of a modified WPC to low-fat whipping cream.

\section{MATERIALS AND METHODS}

\section{WPC Preparation}

Fresh sweet whey was obtained from the Washington State University Creamery (Pullman, WA) as a byproduct of Cheddar cheese making. Fat was removed from the whey by using a DeLaval airtight separator (model no. 392, DeLaval, Burlingame, CA). The whey was pasteurized at $63^{\circ} \mathrm{C}$ for $30 \mathrm{~min}$ to inactivate microorganisms present in the fresh whey. After pasteurization, the whey was concentrated by a factor of 4 times by using a Romicon model HF-LAB-5 ultrafiltration system (Romicon, Woburn, MA), in the same unit as, and according to Lim et al. (2008a). The degree of the whey concentration was calculated using the equation provided in the Romicon UF manual:

$$
\text { Concentration factor }=\frac{\text { weight of whey }}{\text { weight of retentate }} \text {. }
$$

After concentration, the whey was pasteurized a second time at $68^{\circ} \mathrm{C}$ for $30 \mathrm{~min}$ to ensure destruction of adventitious bacteria that might multiply during filtration. It is important to note that severe thermal treatments (above $70^{\circ} \mathrm{C}$ ) result in protein denaturation, accompanied by loss of aqueous solubility and foaming properties (Kester and Richardson, 1984). The concentration of TS of WPC was determined by using standard methods (American Public Health Association, 1998), and then standardized to $8.23 \%$ by adding sterilized deionized water according to the procedure of Lim et al. (2008a). The protein content of the WPC was $3.02 \%$. The WPC was processed from a single lot of sweet whey, and then divided into 2 lots for untreated and HHP-treated WPC. Pressurization of WPC used the same unit and followed the protocol of Lim et al. (2008a). The pressure was set to $300 \mathrm{MPa}$ at an initial chamber temperature of $25^{\circ} \mathrm{C}$, and held for $15 \mathrm{~min}$ to provide enhancement of WPC foaming properties and solubility, as demonstrated in previous research (Lim et al., 2008a,b). Portions of WPC were volumetrically poured into separate Lay-Flat Poly Tubing (Consolidated Plastics Company Inc., Twinsburg, OH; $5.3 \mathrm{~cm}$ wide, $4 \mathrm{~mm}$ thick), cut to desired lengths, and heatsealed at both ends. A bag containing approximately $500 \mathrm{~mL}$ of WPC solution was placed in the chamber of the HHP for 1 cycle. The time to reach $300 \mathrm{MPa}$ was approximately $2 \mathrm{~min}$, and decompression was within 30 s. After exposure to high pressure, HHP-treated WPC was stored at $4^{\circ} \mathrm{C}$ for less than 2 wk until whipping cream was produced (Lim et al., 2008b).

\section{Low-Fat Whipping Cream Preparation}

All ingredients used for whipping cream were weighed using a balance (A and D Engineering Inc., Milpitas, CA). The liquid ingredients, including untreated WPC or HHP-treated WPC, skim milk from the Washington State University Creamery, and cream (Inland Northwest Dairy, Spokane, WA) were mixed in a jacketed Armfield batch pasteurizer (Armfield, Ringwood Hampshire, UK) and heated to $45^{\circ} \mathrm{C}$. Consecutively, solid ingredients, including corn syrup solids (Grain Processing Corporation, Muscatine, IA), Stabilizer WT powder (a proprietary mixture of cellulose gum, carrageenan, and maltodextrin; TIC Gums, Belcamp, $\mathrm{MD}$ ), granulated white sugar (C and H Sugar Company Inc., Crockett, CA), and sodium caseinate (Erie Foods International Inc., Rochelle, IL) were blended before gradually being added to the liquid ingredients, and mixed with an emulsifying head until lump-free. Subsequently, polysorbate 60 (Texturant Systems, Degussa, Atlanta, GA), was added, and mixed thoroughly. The mix was pasteurized at $68^{\circ} \mathrm{C}$ for $30 \mathrm{~min}$ in the jacketed Armfield unit. The whipping creams were cooled by cold water circulated in the jacket. When whipping creams were cooled to $40 \pm 2^{\circ} \mathrm{C}$, Citlali vanilla flavor (Santa Fe Distributing, Dayton, WA) was added. Table 1 presents the formulations used for low-fat whipping creams. After being processed, the whipping creams were refrigerated at $6 \pm 2^{\circ} \mathrm{C}$ for at least $12 \mathrm{~h}$ for hydration of dry ingredients and equilibration of emulsification properties (Smith et al., 1999). 
Table 1. Low-fat whipping cream formulations without whey protein concentrate (WPC), containing untreated WPC, and high hydrostatic pressure (HHP)-treated WPC

\begin{tabular}{lccc}
\hline Ingredient & $\begin{array}{c}\text { Without } \\
\text { WPC, kg }\end{array}$ & $\begin{array}{c}\text { Untreated } \\
\text { WPC, kg }\end{array}$ & $\begin{array}{c}\text { HHP-treated } \\
\text { WPC, kg }\end{array}$ \\
\hline 40\% cream & 3.06 & 3.06 & 3.06 \\
Sugar & 2.04 & 2.04 & 2.04 \\
Corn syrup solids & 1.36 & 1.36 & 1.36 \\
WPC (untreated or HHP-treated) $_{\text {Skim milk (liquid) }}$ & 0.00 & 2.53 & 2.53 \\
Sodium caseinate $^{1}$ & 4.57 & 2.04 & 2.04 \\
Stabilizer WT $^{1}$ & 0.23 & 0.23 & 0.23 \\
${\text { Polysorbate } 60^{2}}_{\text {Vanilla }}$ & 0.037 & 0.037 & 0.037 \\
Total amount & 0.014 & 0.014 & 0.014 \\
& 0.037 & 0.037 & 0.037 \\
\hline
\end{tabular}

${ }^{1}$ A proprietary mixture of cellulose gum, carrageenan, and maltodextrin (TIC Gums, Belcamp, MD).

${ }^{2}$ Texturant Systems, Degussa, Atlanta, GA.

\section{Apparent Viscosity}

The apparent viscosity of low-fat whipping creams was determined in triplicate on each batch of whipping cream using a modular Physica rheometer (Model 320, Paar Physica USA Inc., Glen Allen, VA). Twenty grams of the whipping cream was weighed using an Ainsworth scale (Ainsworth, Denver, CO), and placed in the concentric cylinder (Model CC27) at $6 \pm 2^{\circ} \mathrm{C}$ to simulate the initial temperature condition of the whipping cream during aging (Penna et al., 2006). The external water bath was circulated into the jacket surrounding the rotor and cup assembly of the rheometer system to maintain a set temperature at $6^{\circ} \mathrm{C}$. The shear was achieved through rotational flow between coaxial cylinders, where one cylinder was stationary and the other rotated (Gosta, 1995). The shear rate was programmed for an initial rate of 0.1 rotations per second to a final rate of 300 rotations per second with the logarithmic scale increased every $10 \mathrm{~s}$ as programmed upward (0.1 to $300 \mathrm{~s}^{-1}$ ) and downward (300 to $0.1 \mathrm{~s}^{-1}$ ) uniformly. Consequently, shear rate $\left(\mathrm{s}^{-1}\right)$, shear stress $(\mathrm{Pa})$, and apparent viscosity $(\mathrm{Pa} \cdot \mathrm{s})$ of whipping creams were also obtained (Penna et al., 2006). The apparent viscosity resulting from the selected shear rate and shear stress were obtained by using computer Origin Software version 5.0 (OriginLab, Northampton, MA) and adjusted by the power law model (Goff et al., 1994).

Nonlinear regression was used to estimate values for the flow behavior index (n) and consistency coefficient (K) for low-fat whipping cream formulations based on the shear stress and shear rate of triplicate determinations. The power law model provided the desirable fit of $\mathrm{R}^{2}$ value to relationships between shear stress and shear rate; therefore, the power law model was used to describe the apparent viscosity as a function of the shear rates:

$$
\sigma=\mathrm{K} \gamma^{\mathrm{n}}
$$

where $\sigma$ is the shear stress $(\mathrm{Pa}) ; \mathrm{K}$ is the consistency coefficient $(\mathrm{Pa} \cdot \mathrm{s}) ; \gamma$ is the shear rate (per second); and $\mathrm{n}$ is the flow behavior index (Goff et al., 1994). The appropriate choice of model to adjust the data can be determined by observing the $R^{2}$ values. If the $R^{2}$ value is close to 1.0, the nonlinear regression passes through almost all points of the data in the graph representing the relationship of shear stress and shear rate.

\section{Whipping Time and Overrun}

The whipping bowl and instruments were maintained at $6 \pm 2^{\circ} \mathrm{C}$ to prevent an appreciable temperature increase before whipping by refrigerating the bowl and whisk (Gosta, 1995). Refrigerated whipping creams were whipped using a KitchenAid classic stand mixer model K45SS (KitchenAid, St. Joseph, MI) that delivered 250 $\mathrm{W}$ at a speed control of 10 . The overrun of each batch of whipping cream was determined in triplicate after selected whipping times of $2,3,4,5,6,7$, and 8 min. Before mixing, each whipping cream formulation was transferred to fill a tared beaker; a metal spatula was used to remove excess whipping cream, and the top was leveled with the top of the beaker to achieve a constant volume for each determination. The whipping cream was weighed 3 times to establish the whipping cream weight. After whipping, for each set time in the mixer, a constant volume portion of the whipped cream was removed from the mixing bowl and transferred to an empty tared beaker using a small scoop. Avoiding entrapped air pockets, the whipped cream was weighed as before. The process was repeated 7 times at 1-min intervals for each whipping cream formulation, for a total of $8 \mathrm{~min}$ (Gosta, 1995). The overrun was calculated with the following equation (Phillips et al., 1990): 


$\%$ Overrun $=$
$\frac{(\text { weight of whipping cream })-(\text { weight of whipped cream })}{(\text { weight of whipped cream })} \times 100$.

\section{Foam Stability}

Foam stability of each batch of whipped cream was determined in triplicate by monitoring drainage, or loss of serum, at ambient temperature. The procedure of Phillips et al. (1990) was modified according to the method of Lim et al. (2008a). Foam stability tests were conducted after the whipping cream was whipped for $3 \mathrm{~min}$, the time at which maximum overrun was achieved. After 3 min of whipping, the plastic whipping bowl containing whipped cream was set in a ring stand over a clean, tared beaker to collect serum according to the procedure of Lim et al. (2008a). The weight of the beaker containing serum from the foam was determined after $12 \mathrm{~h}$; the serum collected in the beaker was used as an index of foam stability. Greater drainage meant reduced foam stability. The foam stability was calculated according to the following equation (Phillips et al., 1990; Lim et al., 2008a):

$$
\begin{gathered}
\% \text { Foam stability }= \\
\frac{\text { weight of serum collected }}{\text { weight of initial whipping cream }} \times 100 .
\end{gathered}
$$

\section{Sensory Evaluation}

Low-fat whipped creams prepared from the selected treatments were evaluated using a sensory evaluation duo-trio test. After 3 min of whipping, single servings of the whipped cream were transferred into 3-digit-coded small cups and served to panelists in private booths. Fresh whipping cream was prepared every $15 \mathrm{~min}$ to guarantee that panelists evaluated fresh whipped creams throughout the evaluation.

Fifty-seven volunteers participated in the randomized incomplete block design sensory evaluation panel. Three selected low-fat whipped creams (containing no WPC, untreated WPC, or HHP-treated WPC) were served to the panelists in a single session (block). The 3 low-fat whipped cream formulations were served in a selected order almost an equal number of times, but because the initial goal $(\mathrm{n}=60)$ of panelists was not obtained, equal numbers of whipped cream formulations were not evaluated. A balanced-reference duo-trio test was used to determine the ability of panelists to distinguish differences among whipped cream formulations. The panelists were instructed to circle the number of the whipped cream formulation they felt was equivalent to the reference (labeled REF), and had a 50\% probability of guessing correctly (Lawless and Heymann, 1999). The panelists were also given an opportunity to write individual comments describing the sensory characteristics of the whipped cream.

\section{Statistical Analysis}

A Minitab program (version 8, Minitab Inc., State College, PA) was used to conduct statistical analyses. The differences among mean values of whipping cream properties, including overrun, foam stability, and apparent viscosity, were judged for significance by ANOVA. The variations within means were evaluated by using Tukey's procedure for multiple means separations.

To determine the minimum number of correct sensory judgments and to establish significance at $P \leq 0.05$ and confidence for a duo-trio test for a 1-tailed test, the following equation (Meilgaard et al., 1999) was used:

Minimum number of correct judgments $=$

$$
(z \sqrt{n}+n+1) / 2 \text {, }
$$

where $z=1.64$ and $n=57$.

The equation of Meilgaard et al. (1999) was used and compared with the value of $z$ of the standard normal curve in the table of standard normal curve distributions provided by Ott and Longnecker (2001):

$$
z=(k-0.5 n) / \sqrt{0.25 n},
$$

where $k$ is the number of correct responses and $n$ is the number of panelists.

\section{RESULTS AND DISCUSSION}

\section{Apparent Viscosity}

The power law model was used to describe the apparent viscosity as a function of the shear rate raised to an exponent $(\mathrm{n})$. Solutions with $\mathrm{n}$ values less than 1.0 indicated that apparent viscosity decreased as the shear rate increased, which has been identified as pseudoplastic behavior (Goff et al., 1994). The rheological behavior of milk products is complex and dependent on temperature, concentration, and physical state of the dispersed phase (Kristensen et al., 1997). Cream is a non-Newtonian fluid that follows pseudoplastic flow behavior because the viscosity decreases with increasing shear rate (Lim et al., 2008b). Table 2 summarizes the flow parameters of low-fat whipping creams. When 2 whipping creams are compared, the one with a higher $K$ value and a smaller $n$ value is considered more vis- 
Table 2. Flow parameters of low-fat whipping creams using the power law model ${ }^{1}$

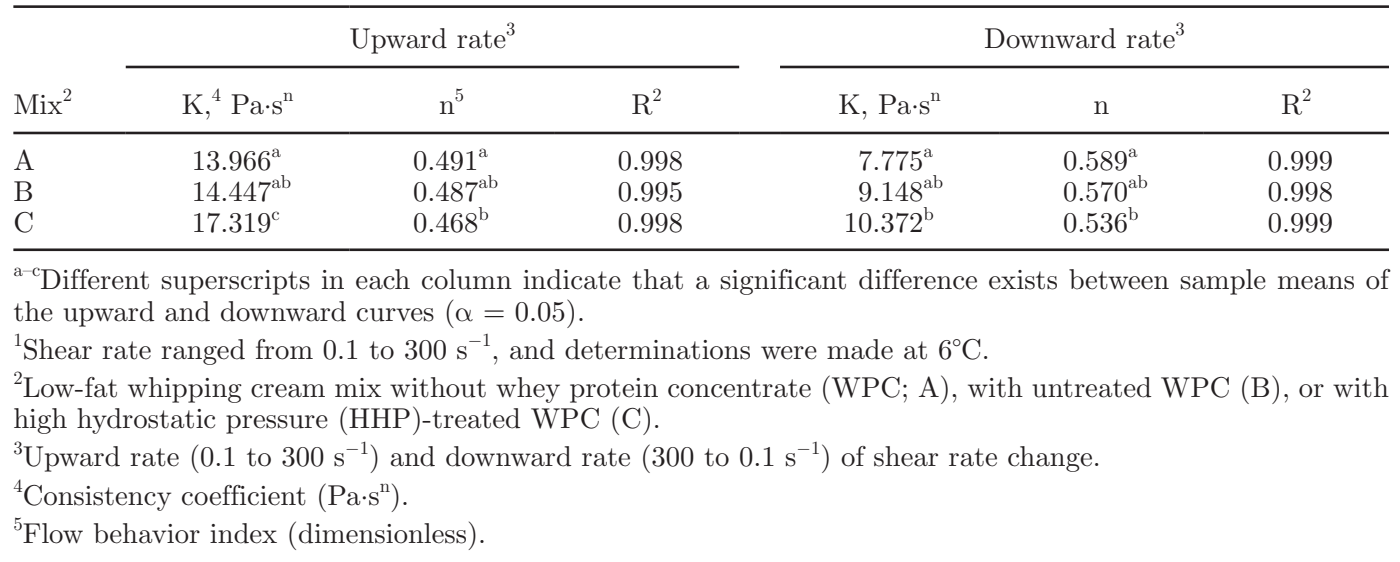

cous. Low-fat whipping cream containing HHP-treated WPC exhibited the largest $K$ value and the smallest $\mathrm{n}$ value for both upward and downward curves of the shear rate change, similar to low-fat ice cream mix (Lim et al., 2008b). The apparent viscosity of low-fat whipping cream containing untreated WPC did not differ significantly from the viscosity of the control lowfat whipping cream (no WPC) or the low-fat whipping cream containing HHP-treated WPC. However, low-fat whipping cream containing HHP-treated WPC was significantly more viscous than low-fat whipping cream without WPC (Table 2; $P \leq 0.05$ ). The apparent viscosity of low-fat whipping cream containing untreated WPC was intermediate between low-fat whipping cream containing no WPC (control) or HHP-treated WPC. The 3 low-fat whipping creams in the present study represented non-Newtonian pseudoplastic behavior, defined by a decrease in apparent viscosity as the shear rate increases, or by an increase in apparent viscosity as the shear rate decreases (Gosta, 1995).

The hydration properties of whey proteins play an important role in viscosity because the protein-water interactions may affect viscosity (Bouaouina et al., 2006). The viscosity of low-fat whipping creams is commonly attributed primarily to hydrocolloids, which modify the texture of food products (Balmaceda et al., 1973). In the present research, the low-fat whipping creams were pasteurized at equivalent temperatures, aged for equal amounts of time, and contained equivalent formulations of ingredients (Table 1). Thus, the variation in consistency was primarily due to the quantity of liquid skim milk and the inclusion of untreated WPC or HHP-treated WPC in the formulations. The presence of HHP-treated WPC increased the apparent viscosity of low-fat whipping cream compared with the absence of WPC.

\section{Whipping Time and Overrun}

The increase in volume attributable to inclusion of air in the structure is called overrun, whereas whipping time is the time required to incorporate air into the food structure. Air is progressively incorporated into the structure of whipping cream during strong agitation, and the cream is transformed into an aerated whipped cream. Low-fat whipping creams achieved the maximum overrun in $3 \mathrm{~min}$. During the initial stage of whipping ( $2 \mathrm{~min}$ ), approximately 62,88 , and $95 \%$ overrun was observed after whipping of formulations A, $\mathrm{B}$, and $\mathrm{C}$, respectively. When whipping continued, the maximum overrun of 73,98 , and $103 \%$, respectively, was determined after whipping times of 3 min (Figure 1). As whipping continued until $8 \mathrm{~min}$, the overrun decreased steadily as the air-water interface structure holding the foam was disrupted by mechanical agitation of the mixer.

The differences of overrun among low-fat whipped creams were attributed to the amount of skim milk and the exclusion or inclusion of WPC. Overrun values of low-fat whipped cream containing HHP-treated WPC and untreated WPC were significantly larger than overrun values of low-fat whipped cream without WPC after whipping times of $3 \mathrm{~min}$ (Figure 1; $P \leq$ 0.05). This finding supports the results of Lim et al. (2008b), who demonstrated that the overrun of lowfat ice cream mix containing HHP-treated fresh WPC was significantly larger than the overrun of low-fat ice cream mix containing commercially spray-dried WPC 35. However, the overrun of low-fat whipped cream containing HHP-treated WPC was not significantly different from that of low-fat whipped cream containing untreated WPC, indicating that the incorporation of WPC into low-fat whipping cream increased overrun 
Table 3. Mean foam stability of low-fat whipped creams expressed as the amount of drainage

\begin{tabular}{lc}
\hline Low-fat whipped cream & Amount of drainage, ${ }^{1} \%$ \\
\hline Without whey protein concentrate & $12.13^{\mathrm{a}}$ \\
Untreated whey protein concentrate & $6.19^{\mathrm{b}}$ \\
High hydrostatic pressure-treated whey protein concentrate & $3.66^{\mathrm{c}}$ \\
\hline${ }^{\mathrm{a}-\mathrm{c}}$ Different superscripts in a column indicate that a significant difference exists between means. \\
${ }^{1}$ Weight of drainage obtained after $12 \mathrm{~h}$ divided by the weight of low-fat whipping cream at the beginning.
\end{tabular}

but that HHP-treatment of WPC did not improve the overrun beyond the WPC itself.

\section{Foam Stability}

Good-quality whipping cream must exhibit a short whipping time, a large overrun, and stable foams (Jakubczyk and Niranjan, 2006). Ideally, the 3-phase system of whipped cream retains a foam structure, and serum leakage will be minimal if the whipped cream is destined for sale in a ready-to-serve form (Drelon et al., 2006). Generally, the air cells of whipped cream are surrounded by a film of partially aggregated fat globules that contribute to foam stability when the degree of fat crystallization in the aggregated fat is adequate (Dickinson and Gelikn, 1992). Foam stability, observed as resistance to collapse, is greatly affected by rheological properties of the continuous water phase as well as by the viscoelastic properties of the interfacial film. Foam collapse is attributed to 3 main forces: drainage or loss of water from the foam, coalescence of air bubbles, and disproportionation of air bubbles as air migrates from small to large air bubbles (Smith et al., 1999).

Low-fat whipping cream containing no WPC had the least and low-fat whipping cream containing HHPtreated WPC had the greatest foam stability. More serum drained from the foam of low-fat whipping cream containing no WPC after $12 \mathrm{~h}$ than from low-fat whipping cream containing untreated WPC or HHP-treated WPC (Table 3; $P \leq 0.05$ ). Low-fat whipping cream containing HHP-treated WPC had significantly greater foam stability than low-fat whipping cream containing untreated WPC (Table 3; $P \leq 0.05$ ). The high stability of the low-fat whipping cream containing HHP-treated WPC was attributed to the HHP-treatment of WPC; denatured WPC produced a cohesive film around the air bubbles. Stable foams require a protein film surrounding air bubbles and the packaging of large amounts of air bubbles into an overall structure (Foegeding et al., 2006). The HHP treatment likely resulted in partial denaturation of the whey proteins, inducing the molten globule state and increasing the hydrophobicity (Yang et al., 2003; Liu et al., 2005b; Lee et al., 2006). Because hydrophobic patches in the open molecule structure stabilize interfaces of proteins between air and water, improved foam stability has been attributed to increased hydrophobicity (Pittia et al., 1996).

The foam stability of proteins is fundamentally related to their film-forming ability at air-water interfaces. In general, proteins that adsorb rapidly at air-water interfaces often exhibit better foam stability than those proteins that adsorb slowly (Caessens et al., 1999; Van der Ven et al., 2002; Foegeding et al., 2006). Partially denatured proteins exhibit better foam stability than rigid and highly ordered proteins, or native proteins (Lim et al., 2008a,b). In the present study, the whipping cream containing HHP-treated WPC, partially denatured protein, exhibited significantly better foam stability than the whipping cream containing untreated WPC, native protein. The foam stability values of lowfat whipping creams were consistent with the results of Lim et al. (2008a), wherein the functional property of WPC most enhanced by HHP in low-fat ice cream mixes was foam stability. Moreover, Lim et al. (2008b) reported that the foam stability of low-fat ice cream mix containing untreated WPC was inferior to low-fat ice cream mix containing HHP-treated WPC. The im-

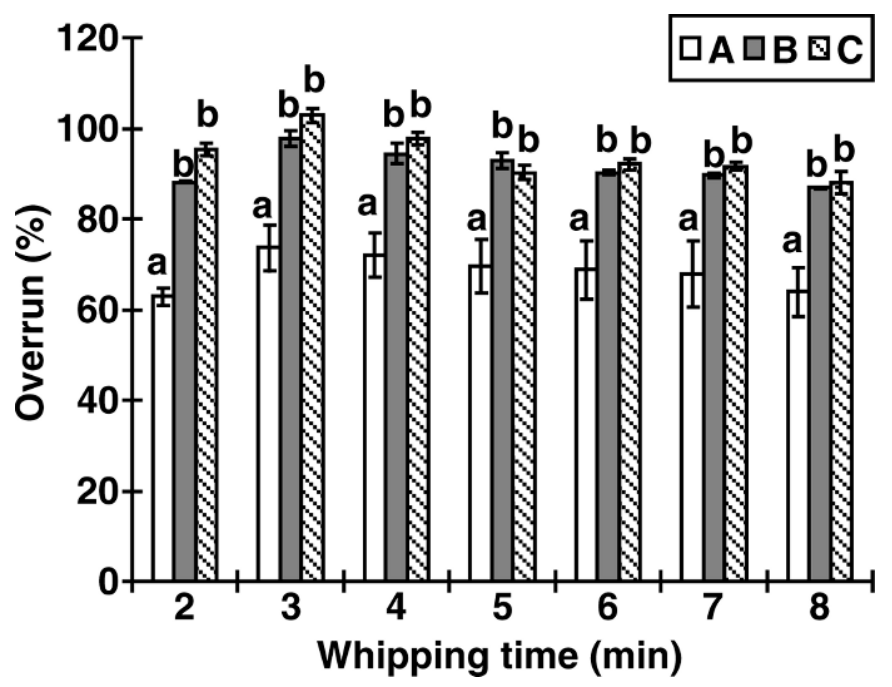

Figure 1. Overrun of low-fat whipped creams after whipping at selected times: $\mathrm{A}=$ without whey protein concentrate $(\mathrm{WPC}) ; \mathrm{B}=$ with untreated WPC; $\mathrm{C}=$ with high hydrostatic pressure-treated WPC. ${ }^{a, b}$ Different letters indicate that significant differences exist among whipping times, $P \leq 0.05$; vertical lines correspond to standard deviations. 
Table 4. Low-fat whipped cream sensory evaluation $(\mathrm{n}=57)$ statistical analysis using the number 35 as a correct judgment required for significance in the duo-trio tests at a probability level of $0.05^{1}$

\begin{tabular}{lccc}
\hline Whipping cream (test) & A vs. B & B vs. C & A vs. C \\
\hline Correct & 32 & 37 & 36 \\
Wrong & 25 & 20 & 21 \\
Significance $(P$-value $)$ & $0.464(P>0.05)$ & $0.012(P \leq 0.05)$ & $0.023(P \leq 0.05)$ \\
\hline
\end{tabular}

${ }^{1}$ Roessler et al. (1978): Meilgaard et al. (1999): Ott and Longnecker (2001). A = without whey protein concentrate (WPC); $\mathrm{B}=$ with untreated WPC; $\mathrm{C}=$ with high hydrostatic pressure-treated WPC.

provements in foam stability for low-fat ice cream mix and low-fat whipping cream produced by HHP-treated WPC hold promise for HHP treatment to improve the foaming properties of WPC.

\section{Sensory Evaluation}

Sensory evaluation is the key to gaining knowledge about whether consumers and panelists perceive differences in a final product. To avoid bias, the panelists were not informed that the whipping creams they were going to taste were low fat. Thus, panelists could focus on the flavor and texture of the whipped cream without preconceived perceptions. A significant difference was not detected between low-fat whipped cream containing no WPC and low-fat whipped cream containing untreated WPC (Table 4; $P>0.05$ ). A significant difference (Table $4 ; P \leq 0.05$ ) was noted between low-fat whipped cream containing untreated WPC and low-fat whipped cream containing HHP-treated WPC. Moreover, the difference between low-fat whipped cream without WPC and low-fat whipped cream containing HHP-treated WPC was significant (Table 4; $P \leq$ $0.05)$.

The ability of the panelists to distinguish a difference between low-fat whipped creams without WPC and low-fat whipped cream containing HHP-treated WPC was consistent with the sensory evaluation of low-fat ice creams reported in previous research (Lim et al., 2008b), in which panelists detected significant differences between low-fat ice cream containing HHPtreated fresh WPC and low-fat ice cream containing untreated rehydrated commercial spray-dried WPC 35. The comments of panelists also indicated that differences in the body and texture of low-fat ice creams were detected (Lim et al., 2008b).

\section{CONCLUSIONS}

Inclusion of HHP-treated WPC in low-fat whipping cream was improved for overrun, viscosity, and foam stability compared with low-fat whipping cream containing no WPC. Not only did physical tests reveal improvement in the low-fat whipping cream, but un- trained panelists also observed significant differences between low-fat whipped creams containing no WPC and low-fat whipped cream containing HHP-treated WPC. Low-fat whipping cream containing HHP-treated WPC had significantly greater foam stability than lowfat whipping cream containing untreated WPC. Moreover, the panelists significantly distinguished between the 2 samples in sensory evaluation. Consequently, use of HHP-treated WPC in low-fat whipping cream exhibits potential to improve foods requiring extended foam stability, which expands the potential application of HHP treatment in the dairy industry.

\section{ACKNOWLEDGMENTS}

This research was funded by the Washington State Dairy Products Commission (Seattle, WA). Special thanks are given to Foremost Farms (Baraboo, WI) for supplying ingredients, and Jaydeep Chauhan (Washington State University) and the Washington State University Creamery staff for assisting with this research.

\section{REFERENCES}

American Public Health Association. 1998. Standard Methods for the Examination of Water and Wastewater. 20th ed. Joint publication of Water Environemnt Federation (WEF), Am. Water Works Assoc., and Am. Pub. Health Assoc. WEF, Alexandria, VA.

Balmaceda, E., C. Rha, and F. Huang. 1973. Rheological properties of hydrocolloids. J. Food Sci. 38:1169-1173.

Banavara, D. S., D. Anupama, and S. A. Rankin. 2003. Studies on physicochemical and functional properties of commercial sweet whey powders. J. Dairy Sci. 86:3866-3875.

Bouaouina, H., A. Desrumaux, C. Loisel, and J. Legrand. 2006. Functional properties of whey proteins as affected by dynamic high-pressure treatment. Int. Dairy J. 16:275-284.

Caessens, P., S. Visser, H. Gruppen, and A. G. J. Voragen. 1999. $\beta$-lactoglobulin hydrolysis. 1. Peptide composition and functional properties of hydrolysates obtained by the action of plasmin, trypsin, and Staphylococcus aureus V8 protease. J. Agric. Food Chem. 47:2973-2979.

Cancino, B., V. Espina, and C. Orellana. 2006. Whey concentration using microfiltration and ultrafiltration. Desalination 200:557558 .

Dickinson, E., and J. L. Gelikn. 1992. Influence of emulsifier on competitive adsorption of $\alpha_{\mathrm{s}}$-casein and $\beta$-lactoglobulin in oil-inwater emulsions. Colloids Surf. 63:329-335.

Drelon, N., E. Gravier, L. Daheron, L. Boisserie, A. Omari, and F. Leal-Calderon. 2006. Influence of tempering on the mechanical properties of whipped dairy creams. Int. Dairy J. 16:1454-1463. 
Foegeding, E. A., P. J. Luck, and J. P. Davis. 2006. Factors determining the physical properties of protein foams. Food Hydrocoll. 20:284292.

García-Risco, M. R., A. Olano, M. Ramos, and R. Lopez-Fandiño. 2000. Micellar changes induced by high pressure. Influence in the proteolytic activity and organoleptic properties of milk. J. Dairy Sci. 83:2184-2189.

Gervilla, R., X. Felipe, V. Ferragut, and B. Guamis. 1997. Effect of high hydrostatic pressure on Escherichia coli and Pseudomonas fluorescens strains in ovine milk. J. Dairy Sci. 80:2297-2303.

Goff, H. D., V. J. Davidson, and E. Cappi. 1994. Viscosity of ice cream mix at pasteurization temperature. J. Dairy Sci. 77:2207-2213.

Gosta, B. 1995. Dairy Processing Handbook. Tetra Pak Processing Systems AB, Lund, Sweden.

Gould, B. W. 2008. Understanding Dairy Market. Agricultural and Applied Economics, UW Madison. http://future.aae.wisc.edu/ data/annual_values/by_area/216?tab=production Accessed Oct. $10,2008$.

Jakubczyk, E., and K. Niranjan. 2006. Transient development of whipped cream properties. J. Food Eng. 77:79-83.

Kester, J. J., and T. Richardson. 1984. Modification of whey protein to improve functionality. J. Dairy Sci. 67:2757-2774.

Kristensen, D., P. Y. Jensen, F. Madsen, and K. S. Birdi. 1997. Rheology and surface tension of selected processed dairy fluids: Influence of temperature. J. Dairy Sci. 80:2282-2290.

Lawless, H. T., and H. Heymann. 1999. Sensory Evaluation of Food: Principles and Practices. Aspen Publishers Inc. Gaithersburg, $\mathrm{MD}$

Lee, W., S. Clark, and B. G. Swanson. 2006. Functional properties of high hydrostatic pressure treated whey protein. J. Food Proc. Preserv. 30:488-501

Li, C. P., H. Enomoto, S. Ohki, H. Ohtomo, and T. Aoki. 2005. Improvement of functional properties of whey protein isolate through glycation and phosphorylation by dry heating. J. Dairy Sci. 88:4137-4145.

Lim, S.-Y., B. G. Swanson, and S. Clark. 2008a. High hydrostatic pressure modification of whey protein concentrate for improved functional properties. J. Dairy Sci. 91:1299-1307.

Lim, S.-Y., B. G. Swanson, C. F. Ross, and S. Clark. 2008b. High hydrostatic pressure modification of whey protein concentrate for improved body and texture of lowfat ice cream. J. Dairy Sci. 91:1308-1316.

Liu, X., J. R. Powers, B. G. Swanson, H. H. Hill, and S. Clark. 2005a. High hydrostatic pressure affects flavor-binding properties of whey protein concentrate. J. Food Sci. 70:C581-C585.

Liu, X., J. R. Powers, B. G. Swanson, H. H. Hill, and S. Clark. 2005b. Modification of whey protein concentrate hydrophobicity by high hydrostatic pressure. Innov. Food Sci. Emerg. Technol. 6:310317.

López-Fandiño, R. 2006. High pressure-induced changes in milk proteins and possible applications in dairy technology. Int. Dairy J. 16:1119-1131.
Meilgaard, M., G. V. Civille, and B. T. Carr. 1999. Sensory Evaluation Techniques. 3rd ed. CRC Press, Boca Raton, FL.

Ott, R. L., and M. Longnecker. 2001. An Introduction to Statistical Methods and Data Analysis. 5th ed. Thomson Learning Inc., Pacific Grove, CA.

Penna, A. L. B., S. Gurram, and G. V. Barbosa-Cánovas. 2006. Effect of high hydrostatic pressure processing on rheological and textural properties of probiotic low-fat yogurt fermented by different starter cultures. J. Food Process Eng. 29:447-461.

Phillips, L. G., J. B. German, T. E. O'Neill, E. A. Foegeding, V. R. Harwalkar, A. Kilara, B. A. Lewis, M. E. Mangino, C. V. Morr, J. M. Regenstein, D. M. Smith, and J. E. Kinsella. 1990. Standardized procedure for measuring foaming properties of three proteins, a collaborative study. J. Food Sci. 55:1441-1444., 1453.

Pittia, P., P. J. Wilde, F. A. Husband, and D. C. Clark. 1996. Functional and structural properties of $\beta$-lactoglobulin as affected by high pressure treatment. J. Food Sci. 61:1123-1128.

Ramaswamy, R. V. M. Balasubramaniam, and G. Kaletunc. 2006. High pressure processing. Facts sheets for food processors. http:// ohioline.osu.edu/fse-fact/0001.html Accessed Apr. 24, 2006.

Relkin, P., and S. Sourdet. 2005. Factors affecting fat droplet aggregation in whipped frozen protein-stabilized emulsions. Food Hydrocoll. 19:503-511.

Rodiles-López, J. O., M. E. Jaramillo-Flores, G. F. Gutiérrez- López, A. Hernández-Arana, R. E. Fosado-Quiroz, G. V. Barbosa-Cánovas, and H. Hernández-Sánchez. 2008. Effect of high hydrostatic pressure on bovine $\alpha$-lactalbumin functional properties. J. Food Eng. 87:363-370.

Roessler, E. B., R. M. Pangborn, J. L. Sidel, and H. Stone. 1978 Expanded statistical tables for estimating significance in pairedpreference, paired difference, duo-trio and triangle tests. J. Food Sci. 43:940-943.

Rosenberg, M. 1995. Current and future applications for membrane processes in the dairy industry. Trends Food Sci. Technol. 6:1219.

Smith, A. K., H. D. Goff, and Y. Kakuda. 1999. Whipped cream structure measured by quantitative stereology. J. Dairy Sci. $83: 1635-1642$

US FDA. 2006. 21 CFR $\S$ 131.57: Milk and Cream. http://www. accessdata.fda.gov/scripts/cdrh/cfdocs/cfCFR/CFRSearch. cfm?fr $=131.157$ Accessed Apr. 20, 2006.

Van der Ven, C., H. Gruppen, D. B. A. de Bont, and A. G. J. Voragen. J. 2002. Correlations between biochemical characteristics and foamforming and stabilizing ability of whey and casein hydrolyzates. J. Agric. Food Chem. 50:2938-2946.

Yang, J., J. R. Powers, S. Clark, A. K. Dunker, and B. G. Swanson. 2003. Ligand and flavor binding functional properties of $\beta$-lactoglobulin in the molten globule state induced by high pressure. J. Food Sci. $68: 444-452$. 